\title{
HERBAGE PRODUCTION OF PASTURE LEGUMES AT THREE SITES IN OTAGO
}

\author{
R. B. Allen":, I. R. McDonald and N. A. Cullen \\ Invermay Agricultural Research Centre, MAF, M osgiel
}

\section{Abstract}

White clover (Trifolium repens), red clover (T. pratense), subterrnnean clover (T. subterraneum) and alsike clover ( $T$. hybridum) were sown singly or in combinations at three sites in Otago. Ryegrass (Lolium perenne) was included in all clover treatments and was also sown alone. Lucerne (Medicago sativa) was sown alone at two sites. Herbage dry matter production was measured over a three-year period. At the high fertility lnvermay site, white and red clovers gave similar total and legume dry matter production and were markedly superior to alsike and subterranean clovers. White and alsike clovers were most productive at the higher altitude, low fertility Berwick site, and at the dry, medium fertility Dunback site red clover produced the highest yields. Lucerne grcatly outyielded all other species in the second and third years at Invermay and in the third year at Dunback.

\section{INTRODUCTION}

A wIDE RANGE of environments exists throughout Otago, including the dry foothill country in North Otago, the infertile acid soils of higher altitude tussock grasslands and the high-fertility alluvial soil of the Taieri Plain.

Although the use of legumes in improved pasture is universal in Otago, little documented evidence is available on legume production, either alone or in grass mixtures.

Trials carried out by McLeod (1968) to determine the production of pasture species in South Canterbury showed that Montgomery red clover was high yielding. Clifford (1973) showed alsike clover to produce well in the MacKenzie Basin, and Harris et al. (1973) demonstrated the value of white clover/ryegrass pasture in Southland.

Lucerne alone and lucerne/grass mixtures were evaluated as hay crops at Invermay, on the Taieri Plain, by Cullen (1965). The results suggested the importance of lucerne as an alternative to pasture in this area.

* Present address: Botany Division, DSIR, P.O. Box 5306, Dunedin. 
The purpose of this investigation was to compare the herbage production of various pasture legumes and ryegrass in different environments in Otago, and to evaluate the use of lucerne as a hay crop in place of pasture.

\section{EXPERTMENTAL}

The trials were laid down in February 1970 on three sites. Invermay, near Mosgiel on the Taieri Plain, was chosen to represent a high-fertility site with adequate rainfall. Dunback, on rolling North Otago downlands near Palmerston, is a moderately fertile dryland site, and Berwick, $20 \mathrm{~km}$ inland in South Otago, is a higher altitude, low-fertility site in tussock grasslands with adequate rainfall. Site details are given in Table 1.

TABLE 1: DESCRIPTION OF SITES

\begin{tabular}{lccc}
\hline & Invermay & Dunback & Berwick \\
\hline Soil type* & Wingatui & Claremont & Waipori \\
$\begin{array}{l}\text { Initial pH } \\
\text { P (Truog) (ppm) }\end{array}$ & $5 . \mathrm{G}$ & 5.0 & 4.8 \\
$\begin{array}{l}\text { Altitude (m) } \\
\begin{array}{l}\text { Mean rainfall } \\
\text { (mm) }\end{array}\end{array}$ & 63 & 23 & 6 \\
$\begin{array}{l}\text { Previous } \\
1967\end{array}$ & 680 & 150 & 550 \\
1968 & Swedes & 560 & 870 \\
1969 & Fodder maize & $\begin{array}{l}\text { Browntop/ } \\
\text { Sweet vernal }\end{array}$ & $\begin{array}{l}\text { Turnips } \\
\text { furnips }\end{array}$ \\
\hline
\end{tabular}

*N.Z. Soil Bureau (1968).

A randomized block layout with four replicates was used, with plot size $6 \times 1.5 \mathrm{~m}$. Treatment details are shown in Table 2. All treatments except lucerne were sown with basal ryegrass, 5.6 $\mathrm{kg} / \mathrm{ha}$ at Invermay and Dunback, and $11.2 \mathrm{~kg} / \mathrm{ha}$ at Berwick. Higher sowing rates were used at Berwick to ensure satisfactory establishment under the harsher environmental conditions. All legumes were inoculated at 20 times the recommended rate.

Each site received $350 \mathrm{~kg} / \mathrm{ha}$ of molybdic superphosphate at sowing, and maintenance dressings of $350 \mathrm{~kg} / \mathrm{ha}$ of superphosphate and $250 \mathrm{~kg} / \mathrm{ha}$ of potassium chloride annually. Lime was applied at rates of $1250 \mathrm{~kg} / \mathrm{ha}$ at Invermay, $2500 \mathrm{~kg} / \mathrm{ha}$ at Dunback, and $5000 \mathrm{~kg} / \mathrm{ha}$ at Berwick, bringing the $\mathrm{pH}$ of each site up to $5.8,5.9$ and 5.4 , respectively. 
TABLE 2: TREATMENTS AND SOWING RATES

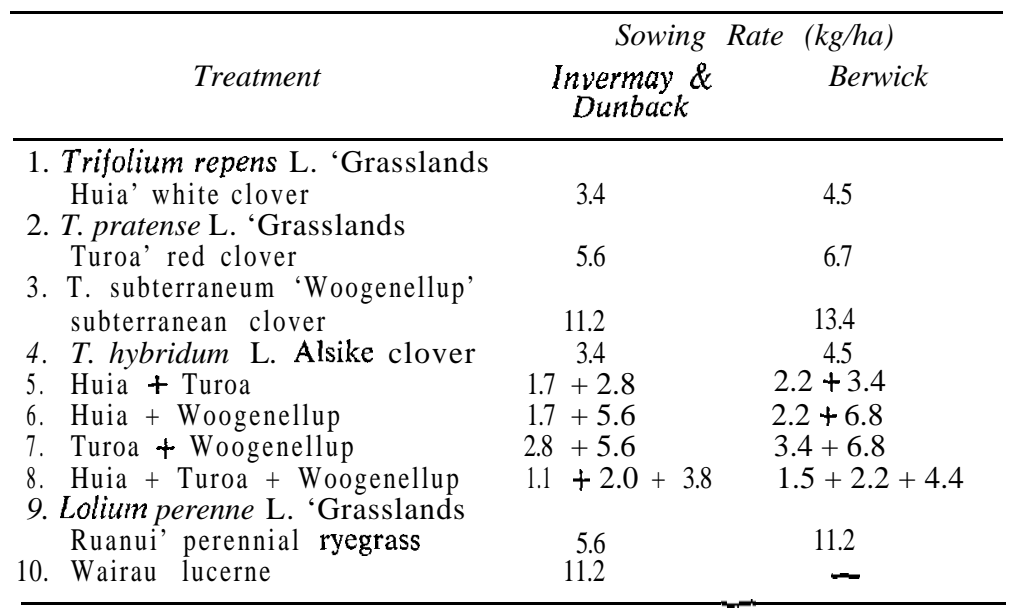

Establishment counts were taken a month after sowing, using 12 random placements of a $232 \mathrm{~cm}$ ' quadrat per plot. Lucerne plots were sprayed with 2,2-DPA (dalapon) nine months after sowing to control grass weed invasion. Clover treatments and ryegrass were cut to $3 \mathrm{~cm}$ when the herbage reached a height of 12 to $15 \mathrm{~cm}$, while the lucerne was harvested when approximately $50 \mathrm{~cm}$ tall. Clover and ryegrass treatments were cut 8 to 9 times annually at Invermay, 4 to 6 times at Dunback and 3 to 4 times at Berwick. Luceme was cut 4 to 5 times annually at Invermay and 0 to 5 times at Dunback. Clippings were not returned to the plots. Herbage samples were dissected into legumes, ryegrass, and other species.

\section{RESULTS}

E S T ABI I S HMENT

Establishment was satisfactory at each site, as indicated in Table 3.

Dry Matter Production

\section{Invermay}

Results are given in Tables 4 and 5, and Fig. 1. Lucerne was not included in the statistical analysis. 

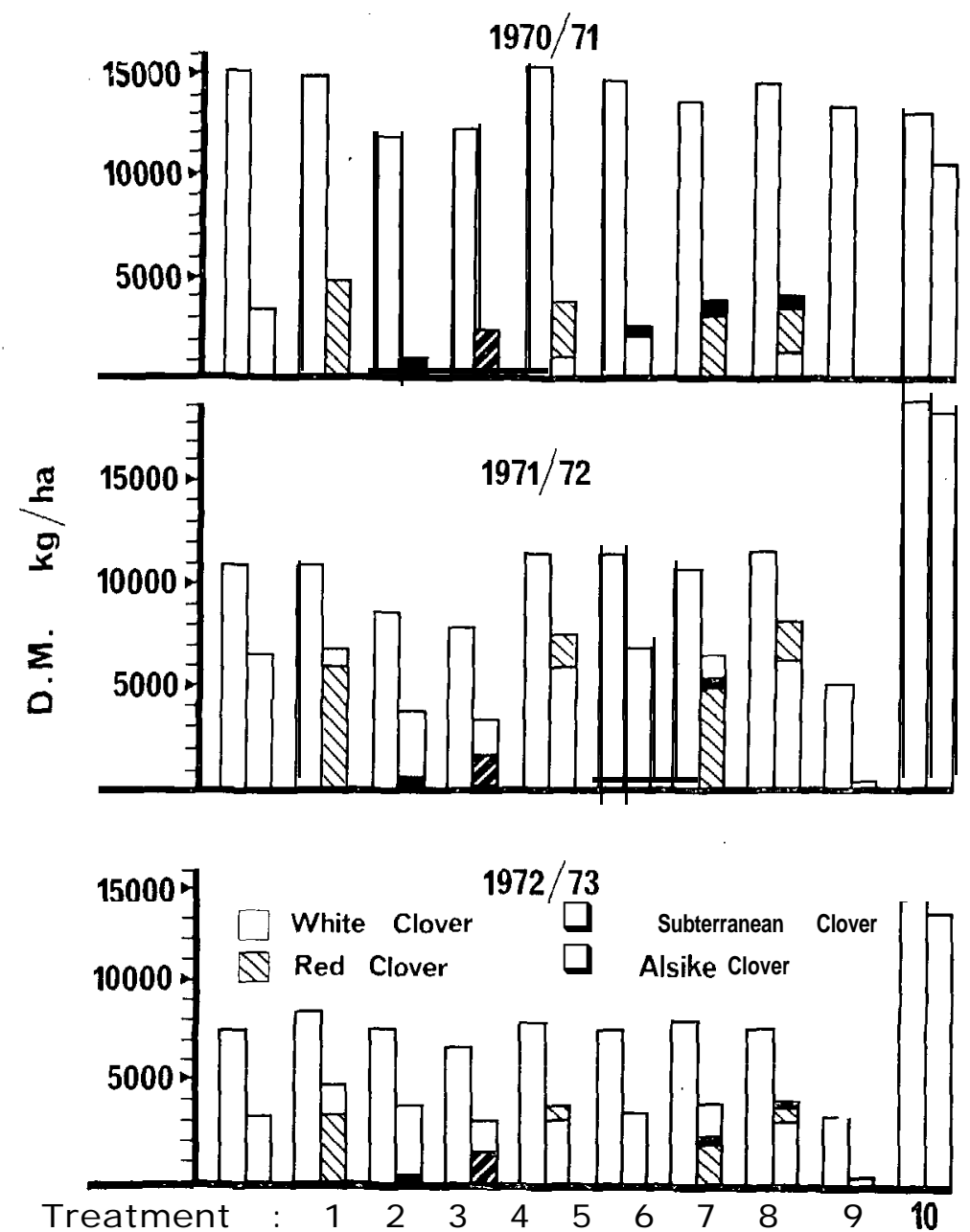

FIG. 1: Dry matter production, Invermay. (In Figs. 1, 2 and 3 the lefthand column of each pair represents total DM production, and the righthand column shows the legume components of DM production.)

\section{Total Dry M atter Yields}

Total dry matter yields were high in the first year, but, with the exception of lucerne, declined in the second and third years.

Production of most clover treatments was similar, but the alsike clover and subterranean clover alone treatments produced significantly less $(P<0.05)$ total dry matter than most other treatments 
PROCEEDINGS N.Z. GRASSLAND ASSOCIATION

TABLE 3: ESTABLISHMENT, PLANTS/me

\begin{tabular}{llcc}
\hline \multicolumn{1}{c}{ Treatment } & \multicolumn{3}{c}{ Site } \\
& Invermay & Dunback & Berwick \\
\hline 1. White clover & 258 & 215 & 280 \\
2. Red clover & 97 & 75 & 97 \\
3. Sub. clover & 43 & 54 & 54 \\
4. Alsike clover & 194 & 129 & 215 \\
5. White clover & 140 & 151 & 194 \\
Red clover & 54 & 54 & 54 \\
6. White clover & 151 & 129 & 183 \\
Sub. clover & 27 & 32 & 27 \\
7. Red clover & 43 & 43 & 48 \\
Sub. clover & 25 & 32 & 32 \\
8. White clover & 108 & 108 & 129 \\
Red clover & 43 & 32 & 32 \\
Sub. clover & 22 & 22 & 32 \\
9. Ryegrass & 172 & 205 & 312 \\
10. Lucerne & 226 & 258 & - \\
\hline
\end{tabular}

TABLE 4: TOTAL HERBAGE DRY MATTER PRODUCTION $\mathrm{kg} / \mathrm{ha}$, INVERMAY

\begin{tabular}{|c|c|c|c|c|}
\hline Treatment & $1970-l$ & $1971-2$ & $1972-3$ & Total \\
\hline 1. White clover & $15000 \mathrm{aA}$ & $10930 \mathrm{aA}$ & $7510 \mathrm{bA}$ & 33440 aA \\
\hline 2. Red clover & $14850 \mathrm{aA}$ & 10940 aA & $8370 \mathrm{aA}$ & $34160 \mathrm{aA}$ \\
\hline 3. Sub. clover & $11830 \mathrm{cc}$ & $8650 \mathrm{bB}$ & $7520 \mathrm{bA}$ & $28000 \mathrm{bB}$ \\
\hline 4. Alsike clover & $12100 \mathrm{bcBC}$ & 7810 bB & $6650 \mathrm{cB}$ & $26560 \mathrm{bB}$ \\
\hline 5. White + Red & 15200 aA & $11350 \mathrm{aA}$ & $7830 \mathrm{abA}$ & 34380 aA \\
\hline 6. White + Sub. & $14500 \mathrm{aAB}$ & $11460 \mathrm{aA}$ & $7570 \mathrm{bA}$ & 33530 aA \\
\hline 7. Red + Sub. & $13730 \mathrm{abABC}$ & $10720 \mathrm{aA}$ & $7920 \mathrm{abA}$ & 32370 aA \\
\hline $\begin{array}{l}\text { 8. White + Red } \\
\text { + Sub. }\end{array}$ & $14490 \mathrm{aAB}$ & $11670 \mathrm{aA}$ & $7650 \mathrm{bA}$ & 33810 aA \\
\hline 9. Ryegrass & $13310 \mathrm{abcABC}$ & $3190 \mathrm{cc}$ & $3310 \mathrm{dC}$ & $19810 \mathrm{cC}$ \\
\hline $\begin{array}{l}\text { 10. Lucerne } \\
\text { CV\% }\end{array}$ & $\begin{array}{c}12990 \\
8.4\end{array}$ & $\begin{array}{l}18970 \\
4.5\end{array}$ & $\begin{array}{c}14010 \\
5.7\end{array}$ & $\begin{array}{l}45970 \\
5.7\end{array}$ \\
\hline
\end{tabular}

In Tables 4, 6 and 8, figures within columns not followed by a common letter differ significantly at the 5\% (lower case) or $1 \%$ (upper case) level of significance. Lucerne is not included in the analysis. 
in the first year, and less $(P<0.01)$ than all other clover treatments in the second year. The alsike clover remained low in the third year.

The ryegrass alone treatment gave significantly smaller $(P<0.01)$ yields than all other treatments in the second and third years.

Lucerne production markedly exceeded that of other treatments in the second and third years, outyielding the. best clover treatments by $63 \%$ and $67 \%$, respectively.

Total production differences between most treatments were small over the three-year period. The alsike clover and subterranean clover alone treatments yielded significantly less $(P<0.01)$ total dry matter than any other clover treatments, while the ryegrass alone yielded less $(P<0.01)$ than any other treatment. Lucerne exceeded the best clover treatment by $34 \%$.

\section{Seasonal and Compositional Production}

Maximum dry matter production of white, red and alsike clovers occurred in summer, with a marked drop in autumn (Table 5). Red and white clovers had similar spring and autumn production where they were sown alone, but red produced $26 \%$ more dry matter than white clover alone in summer. Production of alsike clover and subterranean clover sown alone was low throughout.

Ryegrass contributed the bulk of spring and autumn production in each clover treatment, but clover equalled or exceeded ryegrass production in summer except in the subterranean clover alone treatment.

White clover was the dominant legume in mixtures, producing twice the dry matter of red and far exceeding the yield of subterranean clover.

Ryegrass was dominant in clover treatments in the first year (Fig. 1), and clover dominated in the second. Volunteer clover, composed of white and some suckling clover (T. dubium), formed a substantial proportion of the legume yield of many treatments. During the course of the trial white clover almost completely eliminated subterranean clover, and by the third year formed a substantial proportion of the legume content of the red clover alone treatment.

\section{Dunback}

Results are given in Tables 6 and 7, and Fig. 2. Lucerne was not included in the statistical analysis. 
TABLE 5: SEASONAL AND ANNUAL SPECIES HERBAGE DRY MATTER PRODUCTION (3-YEAR MEANS) kg/ha, INVERMAY

\begin{tabular}{|c|c|c|c|c|c|c|}
\hline Treatment & Species & Spring & Summer & Autumn & $\begin{array}{l}\text { Total } \\
\text { Sown }\end{array}$ & $\begin{array}{l}\text { Volunteer } \\
\text { Legume }\end{array}$ \\
\hline 1 & $\begin{array}{l}\text { White clover } \\
\text { Ryegrass }\end{array}$ & $\begin{array}{l}1280 \\
4 \quad 210\end{array}$ & $\begin{array}{l}2390 \\
1160\end{array}$ & $\begin{array}{l}580 \\
930\end{array}$ & $\begin{array}{ll}4 & 250 \\
6 & 300\end{array}$ & 160 \\
\hline 2 & $\begin{array}{l}\text { Red clover } \\
\text { Ryegrass }\end{array}$ & $\begin{array}{l}1120 \\
3770\end{array}$ & $\begin{array}{r}3010 \\
930\end{array}$ & $\begin{array}{l}560 \\
720\end{array}$ & $\begin{array}{ll}4 & 690 \\
5 & 420\end{array}$ & 810 \\
\hline 3 & $\begin{array}{l}\text { Sub. clover } \\
\text { Ryegrass }\end{array}$ & $\begin{array}{r}350 \\
3790\end{array}$ & $\begin{array}{r}60 \\
1290\end{array}$ & $\begin{array}{r}50 \\
900\end{array}$ & $\begin{array}{r}460 \\
5980\end{array}$ & 2360 \\
\hline 4 & $\begin{array}{l}\text { Alsike clover } \\
\text { Ryegrass }\end{array}$ & $\begin{array}{r}630 \\
3680\end{array}$ & $\begin{array}{r}1010 \\
990\end{array}$ & $\begin{array}{l}130 \\
730\end{array}$ & $\begin{array}{l}1770 \\
5400\end{array}$ & 1120 \\
\hline 5 & $\begin{array}{l}\text { White clover } \\
\text { Red clover } \\
\text { Ryegrass }\end{array}$ & $\begin{array}{r}1280 \\
310 \\
3 \quad 860\end{array}$ & $\begin{array}{l}1750 \\
1100 \\
1210\end{array}$ & $\begin{array}{l}380 \\
190 \\
860\end{array}$ & $\begin{array}{l}3410 \\
1600 \\
5930\end{array}$ & 30 \\
\hline 6 & $\begin{array}{l}\text { White clover } \\
\text { Sub. clover } \\
\text { Ryegrass }\end{array}$ & $\begin{array}{l}1330 \\
100 \\
4 \quad 060\end{array}$ & $\begin{array}{rr}2 & 230 \\
0 \\
1380\end{array}$ & $\begin{array}{r}590 \\
0 \\
950\end{array}$ & $\begin{array}{r}4150 \\
100 \\
6390\end{array}$ & 0 \\
\hline 7 & $\begin{array}{l}\text { Red clover } \\
\text { Sub. clover } \\
\text { Ryegrass }\end{array}$ & $\begin{array}{r}650 \\
260 \\
4 \quad 080\end{array}$ & $\begin{array}{r}2300 \\
130 \\
900\end{array}$ & $\begin{array}{r}380 \\
50 \\
740\end{array}$ & $\begin{array}{r}3 \quad 330 \\
440 \\
5 \quad 720\end{array}$ & 960 \\
\hline 8 & $\begin{array}{l}\text { White clover } \\
\text { Red clover } \\
\text { Sub. clover } \\
\text { Ryegrass }\end{array}$ & $\begin{array}{r}350 \\
210 \\
150 \\
3770\end{array}$ & $\begin{array}{r}1740 \\
1310 \\
40 \\
710\end{array}$ & $\begin{array}{r}380 \\
190 \\
30 \\
860\end{array}$ & $\begin{array}{r}3470 \\
1710 \\
220 \\
5340\end{array}$ & 0 \\
\hline 9 & Ryegrass & 3760 & 1660 & 1090 & 6510 & 150 \\
\hline 10 & Lucerne & 5520 & 6000 & 2490 & 1410 & 0 \\
\hline
\end{tabular}

TABLE 6: TOTAL HERBAGE DRY MATTER PRODUCTION kg/ha, DUNBACK

\begin{tabular}{|c|c|c|c|c|}
\hline Treatment & $1970-I$ & $1971-2$ & $1972-3$ & Total \\
\hline 1. White clover & 6050 & $6830 \mathrm{aAB}$ & 3290 deD & $16170 \mathrm{deBC}$ \\
\hline 2. Red clover & 6020 & $7500 \mathrm{aA}$ & $6180 \mathrm{aA}$ & $19700 \mathrm{aA}$ \\
\hline 3. Sub. clover & 5560 & $5090 \mathrm{c} \mathrm{c}$ & $4400 \mathrm{c} \mathrm{c}$ & $15050 \mathrm{efC}$ \\
\hline 4. Alsike clover & 5860 & $5890 \mathrm{bBC}$ & $3100 \mathrm{eD}$ & $14850 \mathrm{fC}$ \\
\hline 5. White + Red & 5880 & $1350 \mathrm{aA}$ & 4430 c c & 17660 bcB \\
\hline 6. White + Sub. & 5900 & $6930 \mathrm{aA}$ & $3640 \mathrm{dD}$ & $16470 \mathrm{cdBC}$ \\
\hline $\begin{array}{l}\text { 7. Red + Sub. } \\
\text { 8. White + Red }\end{array}$ & 5550 & 6780 aAB & $5580 \mathrm{bB}$ & $17910 \mathrm{bB}$ \\
\hline+ Sub. & 5790 & $7230 \mathrm{aA}$ & $4600 \mathrm{CC}$ & $17620 \mathrm{bcB}$ \\
\hline 9. Ryegrass & 5660 & $2890 \mathrm{dD}$ & $1330 \mathrm{fE}$ & $9880 \mathrm{gD}$ \\
\hline 10. Lucerne & - & 7740 & 8820 & 16560 \\
\hline $\mathrm{CV} \%$ & & 7.6 & 7.1 & 5.2 \\
\hline
\end{tabular}


$\square \quad$ White Clover SI Red Clover
Subterranean Clover

a Alsike Clover
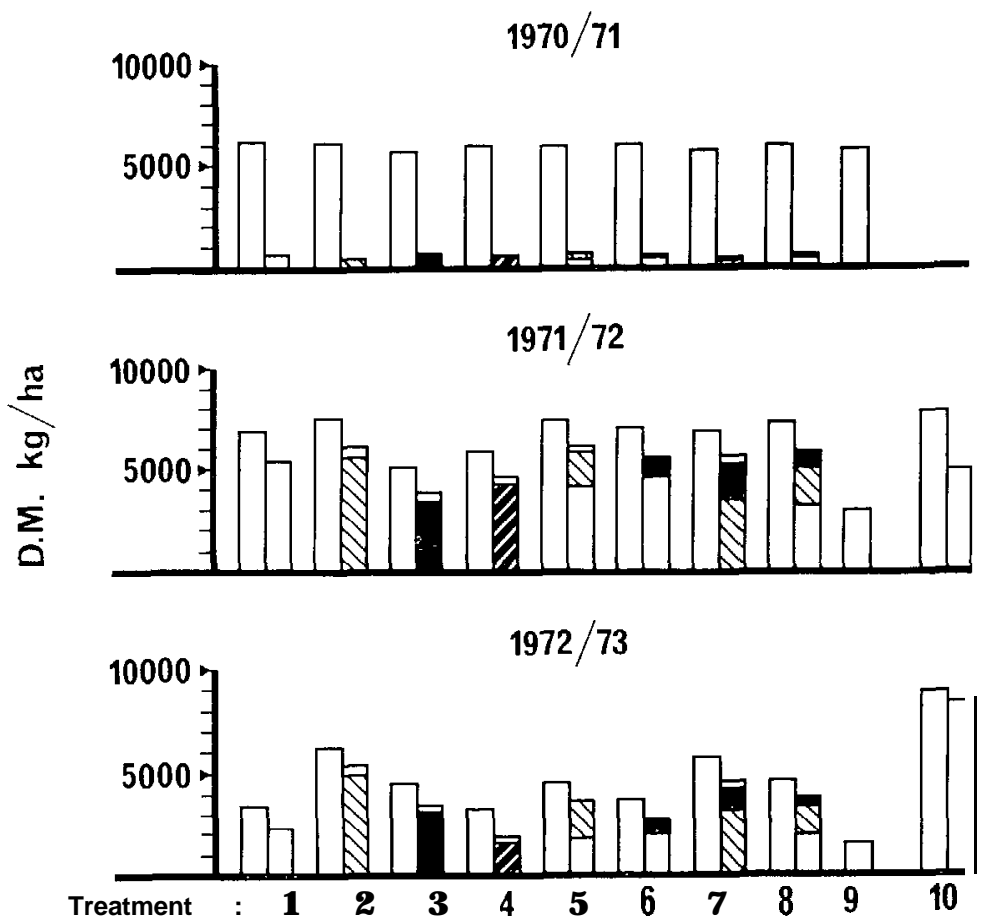

FIG. 2: Dry matter production, Dunback.

Total Dry Matter Yields

Yields of the clover and ryegrass treatments were similar in the first year, but the lucerne was not harvested as little growth had occurred. The yield data from the first year were not statistically analysed.

Although autumn production in the second year was removed by an accidental grazing, yields were similar to or exceeded those of the previous year. In the third year, however, yields of most treatments dropped markedly, and differences between treatments increased.

The alsike clover and subterranean clover alone treatments produced significantly less $(P<0.01)$ total dry matter than other clover treatments in the second year, and the red clover alone 
treatment exceeded $(P<0.01)$ all other treatments except lucerne, in the third year. Yields of ryegrass alone were significantly lower $(P<0.01)$ than those of other treatments in the second and third years.

Lucerne production was similar to that of the higher-yielding clover treatments in the second year, although weeds made up over $30 \%$ of the total dry matter. In the third year lucerne yield exceeded that of the best clover treatment by $43 \%$.

Total dry matter production over the three-year period was significantly higher $(P<0.01)$ in the red clover alone treatment, and lower $(P<0.01)$ in the ryegrass alone treatment, than in any other treatments. Lucerne production was similar to that of clover treatments of intermediate yields.

TABLE 7: SEASONAL AND ANNUAL SPECIES HERBAGE DRY MATTER PRODUCTION (3-YEAR MEANS) $\mathrm{kg} / \mathrm{ha}$, DUNBACK

\begin{tabular}{|c|c|c|c|c|c|c|}
\hline Treatment & Species & Spring & Summer & Autumn & $\begin{array}{l}\text { Total } \\
\text { sown }\end{array}$ & $\begin{array}{l}\text { Volunteer } \\
\text { Legume }\end{array}$ \\
\hline 1 & $\begin{array}{l}\text { White clover } \\
\text { Ryegrass }\end{array}$ & $\begin{array}{l}\mathbf{1 9 1 0} \\
1930\end{array}$ & $\begin{array}{l}690 \\
180\end{array}$ & $\begin{array}{l}210 \\
110\end{array}$ & $\begin{array}{l}2810 \\
2220\end{array}$ & 10 \\
\hline 2 & $\begin{array}{l}\text { Red clover } \\
\text { Ryegrass }\end{array}$ & $\begin{array}{l}1490 \\
2090\end{array}$ & 2090 & $\begin{array}{l}90 \\
80\end{array}$ & $\begin{array}{l}3670 \\
2300\end{array}$ & 170 \\
\hline 3 & $\begin{array}{l}\text { Sub. clover } \\
\text { Ryegrass }\end{array}$ & $\begin{array}{lr}2 & 120 \\
1 & 820\end{array}$ & $\begin{array}{r}60 \\
120\end{array}$ & $\begin{array}{r}100 \\
90\end{array}$ & $\begin{array}{l}2280 \\
2030\end{array}$ & 370 \\
\hline 4 & $\begin{array}{l}\text { Alsike clover } \\
\text { Ryegrass }\end{array}$ & $\begin{array}{l}1300 \\
1860\end{array}$ & $\begin{array}{l}800 \\
140\end{array}$ & $\begin{array}{r}40 \\
110\end{array}$ & $\begin{array}{l}2140 \\
2110\end{array}$ & 110 \\
\hline 5 & $\begin{array}{l}\text { White clover } \\
\text { Red clover } \\
\text { Ryegrass }\end{array}$ & $\begin{array}{r}1620 \\
470 \\
1960\end{array}$ & $\begin{array}{l}420 \\
690 \\
140\end{array}$ & $\begin{array}{r}130 \\
40 \\
100\end{array}$ & $\begin{array}{l}\mathbf{2 1 7 0} \\
1200 \\
\mathbf{2 2 0 0}\end{array}$ & 40 \\
\hline 6 & $\begin{array}{l}\text { White clover } \\
\text { Sub. clover } \\
\text { Ryegrass }\end{array}$ & $\begin{array}{r}1600 \\
\mathbf{4 5 0} \\
1910\end{array}$ & $\begin{array}{r}640 \\
10 \\
160\end{array}$ & $\begin{array}{r}150 \\
40 \\
110\end{array}$ & $\begin{array}{r}2390 \\
500 \\
2 \quad 180\end{array}$ & 30 \\
\hline 7 & $\begin{array}{l}\text { Red clover } \\
\text { Sub. clover } \\
\text { Ryegrass }\end{array}$ & $\begin{array}{r}860 \\
950 \\
1900\end{array}$ & $\begin{array}{r}310 \\
20 \\
140\end{array}$ & $\begin{array}{l}50 \\
40 \\
90\end{array}$ & $\begin{array}{l}\mathbf{2 2 2 0} \\
1010 \\
\mathbf{2 1 3 0}\end{array}$ & 190 \\
\hline 8 & $\begin{array}{l}\text { White clover } \\
\text { Red clover } \\
\text { Sub. clover } \\
\text { Ryegrass }\end{array}$ & $\begin{array}{r}1310 \\
320 \\
340 \\
2000\end{array}$ & $\begin{array}{r}350 \\
800 \\
0 \\
130\end{array}$ & $\begin{array}{r}90 \\
30 \\
20 \\
110\end{array}$ & $\begin{array}{r}1750 \\
1150 \\
\mathbf{3 6 0} \\
\mathbf{2 2 4 0}\end{array}$ & 20 \\
\hline 9 & Ryegrass & 1970 & 160 & 100 & 2230 & 460 \\
\hline 10 & Lucerne & 1980 & 2470 & 90 & 4540 & 0 \\
\hline
\end{tabular}




\section{Seasonal and Compositional Production}

Maximum dry matter production of white, subterranean and alsike clovers occurred in spring, and that of red clover in summer. The spring production of white and subterranean clovers sown alone exceeded that of red and alsike clovers sown alone (Table 7).

Summer production of red clover was $40 \%$ greater than its spring production, but production of the other clovers dropped markedly in summer. Autumn clover yields were low.

Ryegrass and clover yields in most treatments were similar in spring and autumn, but clover yields exceeded those of ryegrass in summer except in the subterranean clover alone treatment.

In mixtures, white clover yields considerably exceeded those of red clover, which exceeded subterranean clover. Levels of volunteer clover, composed mainly of white clover, were low in most treatments.

Production in the first year was almost entirely from ryegrass, but clover dominated production in the second and third years (Fig. 2). The proportions of species in clover mixtures remained relatively constant in the second and third years, and the weed content of the lucerne treatment decreased markedly in the third.

\section{Bet-wick}

Results are given in Tables 8 and 9, and Fig. 3.

TABLE 8: TOTAL HERBAGE DRY MATTER PRODUCTION kg/ha, BERWICK

\begin{tabular}{|c|c|c|c|c|}
\hline Treat ment & 1970-1 & 1971-z & 1972.3 & Total \\
\hline 1. White clover & $2830 \mathrm{aA}$ & 3790 aA & 3960 abAB & $10580 \mathrm{aA}$ \\
\hline 2. Red cl over & $2780 \mathrm{aA}$ & $2660 \mathrm{cdBC}$ & $2810 \mathrm{CC}$ & $8250 \mathrm{abcAB}$ \\
\hline 3. Sub. clover & $2780 \mathrm{aA}$ & $2330 \mathrm{dCD}$ & 3340 abcABC & $8450 \mathrm{abcAB}$ \\
\hline 4. Alsike clover & $2590 \mathrm{abA}$ & $3140 \mathrm{bcAB}$ & $3040 \mathrm{cBC}$ & 8770 abAB \\
\hline 5. White + Red & $2540 \mathrm{abA}$ & 3320 abAB & 3900 abAE & $9760 \mathrm{abAB}$ \\
\hline 6. White + Sub. & $2480 \mathrm{abA}$ & 3810 aA & 4010 aA & $10300 \mathrm{abA}$ \\
\hline 7. Red + Sub. & $2230 \mathrm{bA}$ & $2290 \mathrm{dCD}$ & 3270 bcABC & 7790 bcAB \\
\hline $\begin{array}{l}\text { 8. White + Red } \\
+ \text { Sub. }\end{array}$ & $2860 \mathrm{aA}$ & 3580 abA & $3920 \mathrm{abAB}$ & $10360 \mathrm{abA}$ \\
\hline 9. Ryegrass & $2590 \mathrm{abA}$ & 1770 eD & $1070 \mathrm{dD}$ & $5430 \mathrm{cB}$ \\
\hline $\mathrm{CV} \%$ & 11.8 & 12.0 & 14.9 & 16.0 \\
\hline
\end{tabular}




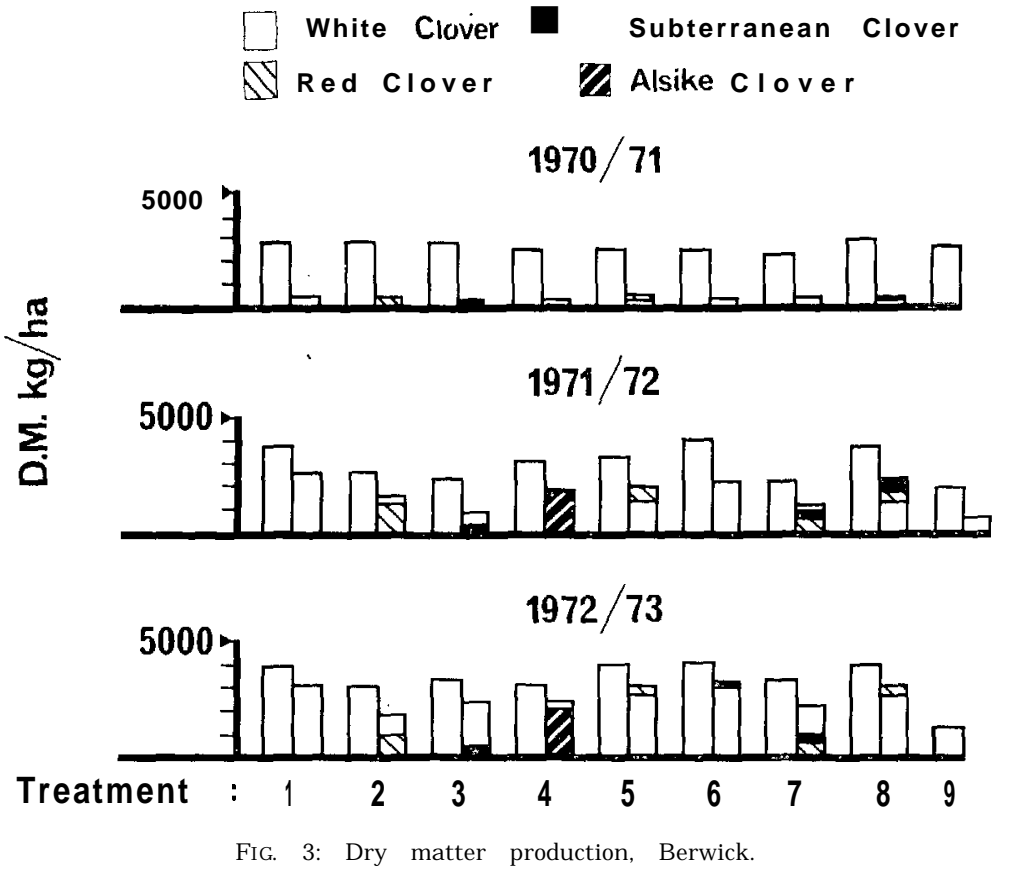

\section{Total Dry Matter Yields}

In the first year, yields of most treatments were similar. Production from white clover treatments increased in the second and third years to give significantly higher $(P<0.05)$ total dry matter than most other treatments. Yield from the alsike clover treatment was similar to that of white clover treatments in the second year.

Ryegrass alone produced significantly less than other treatments in the second $(P<0.05)$ and third $(P<0.01)$ years.

Over the three-year period, total dry matter production of the clover treatments was similar, but the ryegrass alone produced significantly less $(P<0.05)$.

\section{Seasonal and Compositional Production}

White, red and alsike clovers produced approximately twice as much dry matter in summer as in spring. White clover gave the greatest clover yield in each season, although spring production of alsike clover was similar to that of white clover. Subterranean clover production was low throughout (Table 9). 
TABLE 9: SEASONAL AND ANNUAL SPECIES HERBAGE DRY MATTER PRODUCTION (3-YEAR MEANS) kg/ha, BERWICK

\begin{tabular}{|c|c|c|c|c|c|c|}
\hline Treatment & Species & Spring & Summer & A utumn & $\begin{array}{l}\text { Total } \\
\text { Sow n }\end{array}$ & $\begin{array}{l}\text { Volunfeer } \\
\text { Legume }\end{array}$ \\
\hline & $\begin{array}{l}\text { White clover } \\
\text { Ryegrass }\end{array}$ & $\begin{array}{l}570 \\
590\end{array}$ & $\begin{array}{r}1180 \\
370\end{array}$ & $\begin{array}{r}40 \\
160\end{array}$ & $\left.\begin{array}{l}1790 \\
1120\end{array}\right\}$ & 170 \\
\hline 2 & $\begin{array}{l}\text { Red clover } \\
\text { Ryegrass }\end{array}$ & $\begin{array}{l}290 \\
610\end{array}$ & $\begin{array}{l}510 \\
350\end{array}$ & $\begin{array}{r}40 \\
170\end{array}$ & $\left.\begin{array}{r}840 \\
1130\end{array}\right\}$ & 330 \\
\hline 3 & $\begin{array}{l}\text { Sub. clover } \\
\text { Ryegrass }\end{array}$ & $\begin{array}{l}130 \\
700\end{array}$ & $\begin{array}{r}70 \\
430\end{array}$ & $\begin{array}{r}10 \\
200\end{array}$ & $\left.\begin{array}{r}210 \\
1330\end{array}\right\}$ & 840 \\
\hline 4 & $\begin{array}{l}\text { Alsike clover } \\
\text { Ryegrass }\end{array}$ & $\begin{array}{c}500 \\
510\end{array}$ & $\begin{array}{l}880 \\
390\end{array}$ & $\begin{array}{r}20 \\
190\end{array}$ & $\left.\begin{array}{l}1400\} \\
1090\end{array}\right\}$ & 40 \\
\hline 5 & $\begin{array}{l}\text { White clovel } \\
\text { Red clover } \\
\text { Ryegrass }\end{array}$ & $\begin{array}{r}430 \\
70 \\
590\end{array}$ & $\begin{array}{l}880 \\
240 \\
330\end{array}$ & $\begin{array}{r}40 \\
20 \\
160\end{array}$ & $\left.\begin{array}{r}1350 \\
330 \\
1080\end{array}\right\}$ & 70 \\
\hline 6 & $\begin{array}{l}\text { White clover } \\
\text { Sub. clover } \\
\text { Ryegrass }\end{array}$ & $\begin{array}{r}590 \\
30 \\
530\end{array}$ & $\begin{array}{r}1150 \\
20 \\
380\end{array}$ & $\begin{array}{r}40 \\
0 \\
180\end{array}$ & $\begin{array}{r}1780 \\
50 \\
1090\end{array}$ & 110 \\
\hline 7 & $\begin{array}{l}\text { Red clover } \\
\text { Sub. clover } \\
\text { Ryegrass }\end{array}$ & $\begin{array}{l}140 \\
150 \\
470\end{array}$ & $\begin{array}{r}260 \\
50 \\
310\end{array}$ & $\begin{array}{r}20 \\
0 \\
180\end{array}$ & $\left.\begin{array}{l}420 \\
200 \\
960\end{array}\right\}$ & 500 \\
\hline 8 & $\begin{array}{l}\text { White clover } \\
\text { Red clover } \\
\text { Sub. clove1 } \\
\text { Ryegrass }\end{array}$ & $\begin{array}{r}420 \\
50 \\
120 \\
640\end{array}$ & $\begin{array}{r}960 \\
190 \\
20 \\
370\end{array}$ & $\begin{array}{r}30 \\
20 \\
0 \\
200\end{array}$ & $\begin{array}{r}1410 \\
260 \\
140 \\
1210\end{array}$ & 160 \\
\hline 9 & Ryegrass & 650 & 370 & 200 & 1220 & 150 \\
\hline
\end{tabular}

Ryegrass yields were similar to or exceeded total clover yields in most treatments in spring and autumn, Except for the subterranean clover alone treatment, clover yields were greater than ryegrass yields in summer.

White clover gave the highest legume yield of mixtures, and red clover gave twice the yield of subterranean clover where they were sown together.

Volunteer clover, mainly white, made up the majority of production of the subterranean clover alone treatment, and a substantial proportion of production of the red clover alone. Yield from volunteer clover was greater than that of either sown species in the red and subterranean clover mixture.

Production in the first year was almost entirely from ryegrass (Fig. 3). In the second and third years clover became dominant, mainly because of the amount of white clover present in most treatments. Only the alsike clover treatment remained relatively free of volunteer white clover. 


\section{DISCUSSION AND CONCLUSIONS}

Although the technique of mowing and discarding clippings places limitations on the practical applications of this type of trial, the relative production -of species gives some indication of their usefulness in pasture situations.

At Invermay, total herbage dry matter production was high from treatments which included white or red clover (Table 4). Clover contributions to production were important in all seasons, but especially so in summer when ryegrass production dropped markedly (Table 5) .

White clover dominated legume production when sown in mixtures, and legume yields of mixtures seldom exceeded those of white or red clover sown alone (Fig. 1).

As the persistence of red clover is generally low, and as volunteer white clover appears to make up an increasing proportion of legume production in pasture sown only with red clover (Fig. 1), sowing red clover alone is recommended only for seed production.

The results of this trial thus suggested that white clover should be sown with ryegrass for consistently high pasture production on sites similar to Invermay.

As lucerne gave very high yields at the Invermay site, consideration should be given to making greater use of it on similar highfertility soils, in preference to lower-producing clover/ryegrass pasture.

Dry matter production of red clover alone sown with ryegrass was clearly superior to that of the other pasture mixtures at Dunback (Table 6). This agrees with the findings of McLeod (1968) who showed that red clover outyielded both white and subterranean clovers when grown alone, and boosted legume production in most combinations, in a similar environment in South Canterbury. The major factor in this superiority was the good summer growth of red clover in the dry climate of the district. Summer clover production of the red clover alone treatment exceeded twice that of other clovers sown alone, and was greater than that of other clovers when sown in mixtures (Table 7).

Spring total production was similar in treatments containing red or white clover, and autumn production was low in all treatments.

The high total production of the red clover alone treatment and its potential for providing summer grazing when production of other pasture species is declining show that red clover is a suitable legume for sowing in pasture mixtures in a dry, moderately fertile environment. 
Subterranean clover production was comparatively better at Dunback than at the other sites. This may have been due to the adaptation of subterranean clover to low rainfall and regular summer droughts (Smethan, 1968). However, the overall production of subterranean clover does not justify its use as a pasture species at any of the sites described in this paper, although as an annual its seeding and therefore herbage production may have been adversely affected by the mowing management.

The very low production of lucerne at Dunback in the first year is considered normal for this district (G. G. Cossens, pers. comm.) . The high second and third year yields indicate the usefulness of lucerne as a hay crop under this climatic regime.

White clover gave the best legume yields at the Berwick site, although total yields were similar in most treatments (Tables 8 and 9). Legume yields of clover mixtures showed little or no advantage over that of white clover alone (Fig. 3).

Legume production of alsike clover was comparatively high at this site. This agrees with the results of Clifford (1973), who showed alsike clover production to be similar to that of white clover when sown with grasses on a site of moderate to low fertility in the MacKenzie Basin in South Canterbury. Clifford suggested that alsike clover has better ability than other legumes to withstand severe frost and cold.

The results of this trial show white clover to be the pasture legume best suited to the less favourable environment of sites such as that at Bet-wick.

\section{ACKNOWLEDGEMENTS}

The assistance of Invermay Agricultural Research Centre staff in field and laboratory; Biometrics Section with the statistical analyses; G. Cullen, Berwick, and R. W. Pile, Palmerston, for use of their land.

\section{REFERENCES}

Clifford, P. T. P., 1973. Tussock Grasslds \& Mounfain Lands Insf. Rev., 27: 18-21.

Cullen, N. A., 1965. N.Z. Jl agric. R es., 8: 613-24.

Harris, A. J.; Brown, K. R.; Turner, J. D.; Johnston, J. M.; Ryan, D. L.; Hickey, M. J., 1973. N.Z. Jl exp. Agric., 1: 139-63.

McLeod, C. C., 1968. N.Z. Depf A gric. A. Rep. 1967/68_Field Res. Section: 34.

New Zealand Soil Bureau, 1968. General survey of the soils of South Island, New Zealand. N.Z. Soil Bureau Bull. 27.

Smctham, M. L., 1968. Proc. N.Z. Grassld Ass., 30: 114-26. 